Discussion Paper No. 05-31

The Effective Tax Burden of Companies and on Highly Skilled Manpower:

Tax Policy Strategies in a Globalized Economy

Christina Elschner, Lothar Lammersen,

Michael Overesch and Robert Schwager

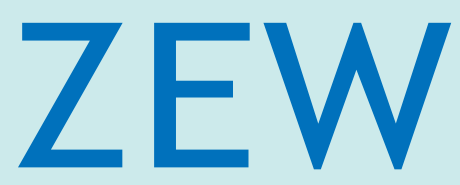

Zentrum für Europäische Wirtschaftsforschung $\mathrm{GmbH}$

Centre for European

Economic Research 
Discussion Paper No. 05-31

\title{
The Effective Tax Burden of Companies and on Highly Skilled Manpower: Tax Policy Strategies in a Globalized Economy
}

\author{
Christina Elschner, Lothar Lammersen, \\ Michael Overesch and Robert Schwager
}

Download this ZEW Discussion Paper from our ftp server:

ftp://ftp.zew.de/pub/zew-docs/dp/dp0531.pdf

Die Discussion Papers dienen einer möglichst schnellen Verbreitung von neueren Forschungsarbeiten des ZEW. Die Beiträge liegen in alleiniger Verantwortung der Autoren und stellen nicht notwendigerweise die Meinung des ZEW dar.

Discussion Papers are intended to make results of ZEW research promptly available to other economists in order to encourage discussion and suggestions for revisions. The authors are solely responsible for the contents which do not necessarily represent the opinion of the ZEW. 


\section{Non-Technical Summary}

Companies pay taxes on profits and capital. Also, under competitive markets for highly skilled labour, firms have to compensate employees for international differences in labour tax burdens. Both elements thus constitute a tax burden on companies and influence the attractiveness of a particular region as a location for investment. The present paper combines the two indicators so as to allow for a comprehensive picture of the level of taxation relevant for companies at various locations. The synthesis offered here permits a deeper understanding of the challenges faced by tax policy in various countries, of the strategies chosen to address them, and of the political institutions and economic circumstances determining these choices.

For this purpose, we present and compare estimates of the effective level of taxation in 33 selected locations across Europe and the United States. For each country, there is both a measure of the effective tax burden on profits and capital and a measure for the effective tax burden on highly skilled manpower. The computations of effective tax burdens on capital investment are based on the model developed by Devereux and Griffith. For the determination of effective tax burdens on highly qualified manpower we developed a simulation model that accounts for several components of the remuneration package, the family status, and varying points in time of taxation.

By combining the two indicators we find that there is great dispersion in the effective tax rates of both factors of production. Swiss regions show low tax burdens for both indicators. East European and Scandinavian regions display low effective tax rates on capital investment but moderate or high effective tax rates on highly qualified manpower. France, Germany, and Italy tax companies and highly qualified employees at a high level. The United States display moderate tax rates on highly qualified labour and high tax rates on capital investment.

We identify three potential causes in order to explain the different tax policy strategies of different countries: (1) political institutions, (2) preferences for redistribution and equality, and (3) the position in globalisation and growth. The first two categories mainly concern the income tax revenue and the tax burden on individuals; the latter category rather concerns the tax burden on the mobile factor capital investments. Our findings on the effective tax rate of companies and highly skilled manpower strongly reflect these different tax strategies. However, each country shows a mix of tax strategies which lead to the country-specific tax burdens. Small countries, high growth rates, and federal structure with high tax autonomy stand for countries that offer lower tax burdens, especially on companies. As examples for this group of countries we can identify e. g. Ireland and Switzerland, however, each with certain limitations. Most new EU member states follow a strategy of taxing companies comparatively low, but offer only an average tax climate for highly skilled employees. Large countries, representative democracies with coalitions, and a high preference for redistribution are likely to induce higher tax burdens on both highly qualified employees and companies and thus are less attractive locations for an investment from a tax perspective. As typical examples for this group of countries, we identify Germany, France, and Italy. The low tax rates for the highly skilled in the United States therefore stand for her plurality system, her federal structure, and a population with low preference for redistribution. Due to her size the United States do not need to tax companies at low rates. 


\title{
The Effective Tax Burden of Companies and on Highly Skilled Manpower: Tax Policy Strategies in a Globalized Economy
}

\author{
Christina Elschner ${ }^{*}$, Lothar Lammersen ${ }^{*}$, Michael Overesch ${ }^{*}$, Robert Schwager ${ }^{* *}$
}

April, 2005

JEL: H21, H24, H25,

Keywords: effective tax burden, tax policy, company taxation, personal income tax

\begin{abstract}
Company taxes and taxes on highly skilled labour both influence the attractiveness of a particular region as a location for investment. We measure the effective tax burden on capital investment and on highly qualified labour in 33 locations across Europe and the United States. We then correlate both types of tax burden in order to study the different tax policy strategies applied in different countries. We identify three causes for different strategies: political institutions, preferences for redistribution and equality, and the position in globalisation and growth. Small countries, high growth rates, and federal structure with high tax autonomy stand for countries with lower tax burdens, especially on companies. Large countries, representative democracies with coalitions, and a high preference for redistribution are likely to induce higher tax burdens.
\end{abstract}

\footnotetext{
${ }^{*}$ Centre for European Economic Research (ZEW) and University of Mannheim

** Georg-August-University of Göttingen and Centre for European Economic Research (ZEW)
} 


\section{Introduction}

Companies pay taxes on profits and capital. Also, under competitive markets for highly skilled labour, firms have to compensate employees for international differences in labour tax burdens. Both elements thus constitute a tax burden on companies and influence the attractiveness of a particular region as a location for investment. While there exist numerous studies on the tax burden on capital investment on the one hand (see for example, Devereux et al., 2000, 2001 and European Commission 2002) and several studies on labour taxation on the other hand (OECD, 2002 or Sutherland, 2001) there is no study covering and combining both aspects of tax burden. The present paper aims at filling this gap so as to allow for a comprehensive picture of the level of taxation relevant for companies at various locations. The synthesis offered here permits a deeper understanding of the challenges faced by tax policy in various countries, of the strategies chosen to address them, and of the political institutions and economic circumstances determining these choices.

For this purpose, we present and compare estimates of the effective level of taxation in several European countries and the United States. ${ }^{1}$ For each country, there is both a measure of the effective tax burden on profits and capital and a measure for the effective tax burden on highly skilled manpower. Although both indicators rely on different models for estimating effective tax burdens, both models share the same spirit. Therefore, we can compare the qualitative results of both parts, and we can draw common conclusions.

Due to the great number of relevant tax rules, effective tax burdens may differ significantly from statutory tax burdens. Our analysis contributes to theoretical research on taxation by providing meaningful quantitative estimates of effective tax burdens. These estimates take into account the most important rules of all the relevant taxes. For company taxation, we include the corporation tax with surcharges, other profit related taxes, real estate taxes, and specific taxes based on capital. For the taxation of highly skilled manpower, we consider income taxes including surcharges, tax-like social security contributions as well as wage taxes paid by the company.

In order to quantify and compare effective company tax burdens, we calculate effective average tax rates (EATRs), which are relevant for international location decisions, ${ }^{2}$ and effective marginal tax rates (EMTRs), which are important indicators for a firm's investment opportunities and competitiveness from a tax perspective at a given location. The computations are based on the model developed by Devereux and Griffith, ${ }^{3}$ which builds on and extends the approach by King and Fullerton (1984, pp. 7-30). Both concepts have already been used for a number of international tax burden comparisons. ${ }^{4}$

\footnotetext{
${ }^{1}$ The estimations were prepared for the «IBC BAK International Benchmark Club» ${ }^{\circledR}$, which evaluates and compares economic performance and location factors across European regions. The headline figures represent the IBC Taxation Index (see Table 2 and Table 3). The purpose of the IBC being the benchmarking of location factors on a regional basis, the project produces effective tax rates for companies in 161 regions in the 18 countries studied. In the present paper, we restrict attention to the national level by presenting only the median value for the included countries. Additionally, we present regional results for Switzerland, where the inter-regional variation is most pronounced, and the minimum and maximum corporate tax burden of the included regions in Germany and France. Detailed results can be found in Lammersen and Schwager (2005) and Elschner and Schwager (2005).

${ }^{2}$ See Richter et al. (1996), p. 19; Devereux and Griffith (1998); Büttner and Ruf (2004).

${ }^{3}$ See Devereux and Griffith (1999); Devereux and Griffith (2003); Schreiber et al. (2002).

${ }^{4}$ See, e.g., Gutekunst and Schwager (2002), European Commission (2002), Sachverständigenrat (2001) pp. 308316, (2003) pp. 354-360; Jacobs et al. (2004).
} 
For the measurement of the tax burden on highly skilled manpower, we cannot return to a well-established methodology. Existing analyses focus on average production workers, such as OECD (2002), or do not consider the tax burden on employees as an issue for the firm, such as the Euromod project (Sutherland, 2001). Concerning highly skilled employees, this is unsatisfactory since these employees generally receive sophisticated compensation packages and are highly mobile. ${ }^{5}$ To account for the former, an approach has been developed which allows to consider several components of the remuneration package, the family status, and varying levels of compensation. ${ }^{6}$ This concept parallels established methodologies for the quantification of company tax burdens by calculating the effective average tax rate (EATR) as an indicator of the tax burden. Mobility implies that employers compete for highly qualified employees and therefore have to compensate them for taxes on labour income and tax-like social security contributions. As a consequence, we compare the tax burden of different regions for a given disposable income after taxes which the employee can obtain at all locations.

For regional and national policy makers, the results of our study can be interesting since taxation is deemed to be an important location factor. For company taxation, this has been well established empirically. Thus, Büttner and Ruf (2004) show that location decisions of German multinationals are strongly affected by differentials in statutory as well as effective average tax rates. This is in line with De Mooij and Ederveen (2003) who conclude from a survey of empirical research that aggregate flows of foreign direct investment are strongly affected by taxation. Although less well documented empirically, the tax burden on mobile employees is likely to be an important location factor for firms, too. Our study contributes to assess the attractiveness of different locations from a tax perspective by comparing effective tax burdens inter-regionally and internationally. In particular, the joint consideration on taxes on both capital and skilled labour allows evaluating the strengths and weaknesses of locations more comprehensively than would be possible by an isolated look at corporate tax rates.

An effective tax rate is always the result of each particular case. To identify the general context and to find out the most relevant tax provisions in different economic constellations - the so-called tax drivers - the study examines the effect of important tax provisions on effective tax burdens. Thus, an additional benefit of our research consists of improving the understanding of the link between specific legal provisions and the ensuing tax burden.

In the remainder of the paper, we first present the estimates on company taxation (Section 2) and on the taxation of highly skilled employees (Section 3) separately. In these sections, we give a brief account of the models we use and our major results. In Section 4, we combine these findings so as to allow for a general discussion of tax policy strategies pursued by the countries studied. Section 5 offers some concluding remarks.

\section{Company Taxation}

\subsection{The Model}

The Devereux/Griffith model considers an incremental, hypothetical corporate investment. The investment we assume consists of five different types of assets (intangibles, industrial

\footnotetext{
${ }^{5}$ Winkelmann (2002) and Winkelmann et al. (2001) provide evidence on the extent of international mobility of highly skilled employees.

${ }^{6} \mathrm{~A}$ formal description is provided in Elschner and Schwager (2004).
} 
buildings, machinery, financial assets, and inventories). We take three different sources of finance into account: retained earnings, new equity, and debt. The hypothetical investment takes place in the beginning of a period and generates a return in its end. Thus, we suppose a one-period perturbation of the capital stock. We measure the cash flows connected with this investment and compute various measures of effective tax rates. Fig. 1 describes the structure of the model.

Fig. 1: Structure of the model

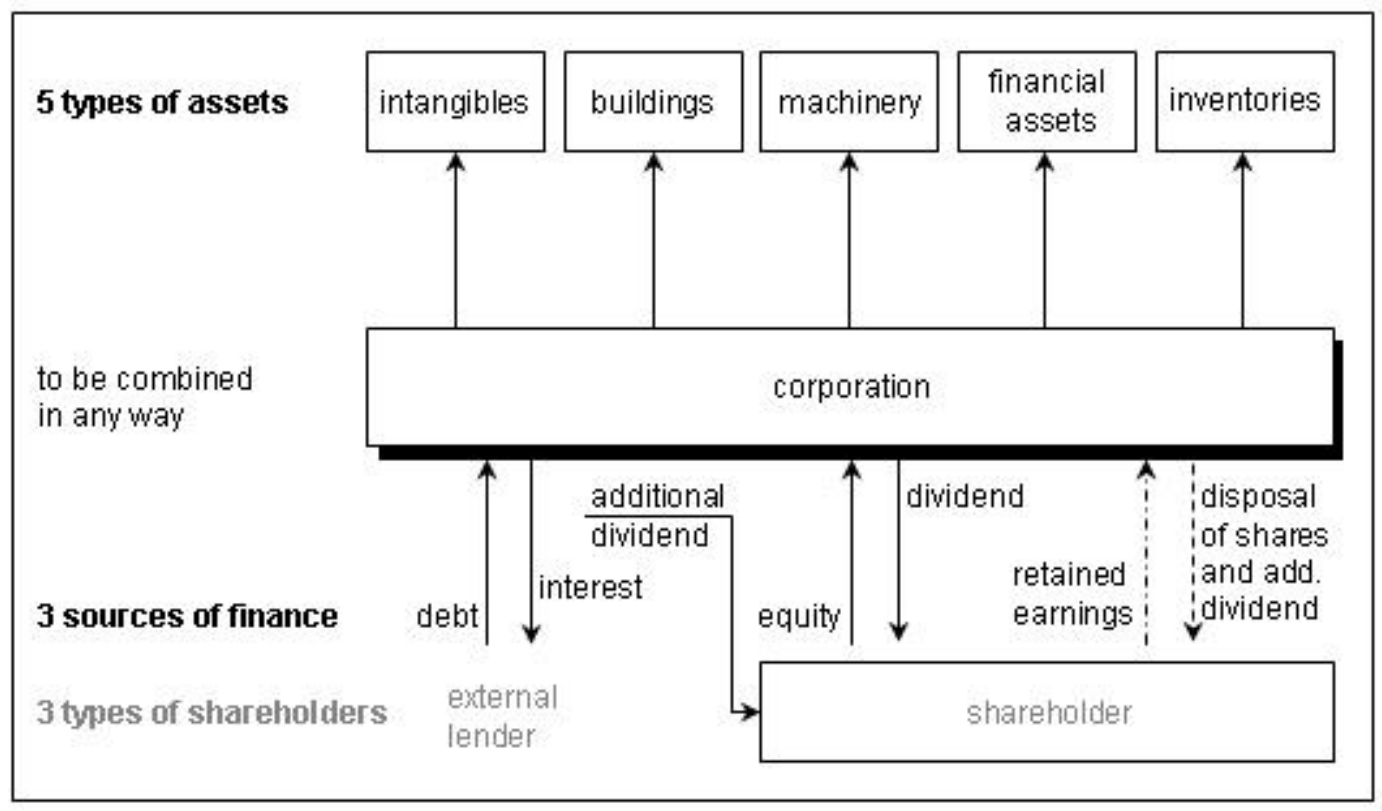

Before the background of a neoclassical economic framework, the model considers several important economic parameters: the unique market interest rate, the rate of inflation, geometrically declining economic depreciation of intangibles, industrial buildings and machinery, and the pre-tax rate of return on the investment. In order to isolate the effects of taxation from other economic effects, these economic parameters are exogenous, except for the calculation of the pre-tax rate of return of a marginal investment. This means that their values are supposed to be equal for all investments regardless of their location. Consequently, real interest rates and also nominal interest rates are equal across all the locations and regardless of the level of profitability of an investment. In the base case, we assume a corporation in the manufacturing sector which undertakes a particular mix of investments and uses a particular combination of sources of finance. Table 1 presents the assumptions of the calculations.

Table 1: Assumption of the calculations

\begin{tabular}{lll}
\hline Assumption on ... & Value & \\
\hline Legal form & Corporation & \\
Industry & Manufacturing Sector & \\
Assets & $\begin{array}{l}\text { Intangibles, industrial } \\
\text { assets, inventories (at equal weights) }\end{array}$ & buildings, machinery, financial \\
Sources of finance & Retained earnings (55\%), new equity (10\%), debt (35\%) \\
True economic depreciation & $\begin{array}{l}\text { Intangibles } \\
\text { Industrial buildings }\end{array}$ & -12.5 years \\
& Machinery & -11 years \\
Real interest rate & $5 \%$ & \\
$\begin{array}{l}\text { Pre-tax real rate of return } \\
\text { (for calculation of EATR) }\end{array}$ & $20 \%$ & \\
Inflation rate & $2 \%$ & \\
\hline
\end{tabular}


The study focuses on the effective tax burden at the corporate level, which is especially relevant for the choice of location of international corporations. ${ }^{7}$ Therefore, we include taxes on corporate income and capital. The effective tax rates computed for each region comprise taxes levied at the national, the state and the municipal level. The calculations consider the statutory tax rates of these taxes as well as the interaction of different kinds of taxes and the most important rules determining the tax base, e.g. differences in depreciation allowances and inventory valuation.

\subsection{Results}

We express the headline results by the EATR, which indicates the effective tax burden on a very profitable investment. It is defined as the difference between the pre-tax and the post tax rates of return of an investment, divided by the pre-tax rate of return. This measure also represents the IBC Taxation Index for companies.

The results indicate that there is considerable dispersion of the EATRs between the countries and regions considered (see Table 2). The EATRs range from 13.8\% in the Swiss canton Zug to $37.3 \%$ as the maximum tax burden in Germany. Whereas Ireland and Switzerland display comparatively low effective tax burdens, locations in France, Germany, and the United States show the highest EATRs. This finding suggests that the attractiveness of particular locations from a tax perspective differs dramatically, with Switzerland and Ireland as especially attractive countries.

In 2003, the effective tax burden in the selected new member states of the EU is in comparison rather low. Only a few Swiss cantons and Ireland show lower tax burdens in terms of the EATR than found for Hungary, Slovenia, and Slovakia. Given amendments and alterations in the tax systems, we additionally calculate effective tax burdens of companies for the accession countries based on the tax rules effective in 2004. Except for the Czech Republic, these changes in the tax systems significantly decrease the effective tax burden in these five accession countries, further improving their attractiveness.

We express a second set of results by the EMTR. In contrast to EATRs, EMTRs indicate the effective tax burden on an investment that is marginal in economic sense, i.e. an investment that earns a net present value of zero. Such an investment limits the profitable investment opportunities of a company. The lower the EMTR at the corporate level, the larger is the theoretically optimal level of investment. Also, a firm that faces a lower EMTR on its investment is deemed to have a competitive advantage over its competitors who face greater EMTRs.

The dispersion of effective marginal tax rates between the assessed regions is even greater than the dispersion of effective average tax rates. It ranges from -11\% in Slovenia in the case where some special investment incentives fully apply up to $36.2 \%$ in Isère, France (see Table 2). The negative EMTR in the Slovenian incentive case means that the cost of capital is below the real interest rate, implying that investment in fact is subsidised in Slovenia. These results suggest that the optimal level of investment and the competitiveness of companies located in

\footnotetext{
${ }^{7}$ The non-consideration of taxes at the shareholder level is adequate in case managers do not know the tax position of their marginal shareholder. However, domestic shareholder taxation does not affect corporate investment decisions of multinationals under substantial international capital mobility. For a discussion of these issues see European Commission (2002), p. 142 f., or Spengel (2003), pp. 81-85. The effective tax rates at the combined levels of the corporation and the shareholder are reported in Lammersen and Schwager (2004 and 2005).
} 
different regions also differ dramatically from a tax perspective. There is also a strong impact of targeted measures like investment tax credits or dual income taxes. Therefore, Austrian or Slovenian companies that can take full advantage of such measures display very low EMTRs. On the other side, there is a disadvantage for companies which have to pay substantial nonprofit taxes. Non-profit taxes weigh especially heavily on investments with a low rate of return. France, e. g., imposes a comparatively strong non-profit tax in form of the taxe professionnelle. Consequently, the attractiveness of France as expressed by the EMTR is even lower than the one expressed by the EATR.

Statutory profit tax rates are found to be very important tax drivers for profitable investments. However, tax burdens always depend on the individual characteristics of each investment, thus special rules regarding the tax base or property taxes may be very relevant in particular cases. French corporations carry an extra tax burden in form of the taxe professionnelle, whereas Italian corporations take advantage of a comparatively favourable definition of the corporate tax base. Although the combined statutory profit tax rate in Italy (38.25\%) is significantly higher than the one in France (35.43\%), effective tax burdens are lower in Italy than in France.

Sensitivity analyses reveal some interesting mechanics of the impact of taxation on effective tax burdens. E.g., the impact of French non-profit taxes heavily depends on the relative importance of fixed assets in the investment mix. French regions significantly improve their position compared with German regions when corporations are considered which hardly rely on buildings and machinery, as it is the case e.g. in the service sector. However, although some notable changes in the rankings occur, these changes are not strong enough to fundamentally challenge the main conclusions from the base case. With respect to EMTRs, the impact of the economic assumptions on the ranking is stronger than with respect to EATRs. Particular tax rules, e.g. the generosity of depreciation allowances, play a more prominent role, and the particular features of each individual investment become more important in determining the most tax efficient location. The weight of the statutory profit tax rate compared with the weight of various tax drivers increases along an increasing pre-tax rate of return.

\section{Taxation of Highly Skilled Manpower}

\subsection{The Model}

In our approach, we evaluate the tax burden on a highly skilled employee for a given disposable income after taxes. To achieve this, we perform two steps. At first, we conduct the tax assessment of a typical qualified employee's income before taxes (the total remuneration). If the resulting income after taxes falls short of (exceeds) the required disposable income, in a second step we repeat the assessment for a higher (lower) total remuneration. We then iterate until the total remuneration necessary to obtain the predetermined disposable income is found. The effective average tax rate then is equal to the difference between total remuneration and disposable income (the tax wedge) divided by the total remuneration.

Taxes in this context are all income taxes including surcharges and state and municipality taxes, as well as payroll taxes paid by the company. Social security contributions are part of the tax burden inasmuch as the employee does not earn a specific, individual benefit by paying them. According to the basic idea of competition, there is little risk of unemployment for the kind of qualified employees considered in this study. Hence we define contributions to unemployment insurance, and by a similar reasoning also contributions to accident insurance, 
as taxes. On the other hand, we consider health insurance contributions not to be taxes since they are deemed to provide a genuine insurance.

Contributions to public pension schemes qualify partly as taxes. The first pillar of old-age insurance is usually organised as a pay as you go system involving redistribution between generations and between high and low earning workers. Inasmuch contribution payments do not result in actual fair pension entitlements, they constitute an implicit tax rather than an insurance premium. To account for this implicit tax, we compute entitlements earned by the highly qualified employee according to the legislation currently in force and offset against contributions.

Our model distinguishes between three kinds of compensation: (1) cash compensation, (2) contributions to old-age provisions, and (3) benefits in kind. These components are taxable in different periods. Cash compensation and benefits in kind are taxable income in the year of payment. Contributions to old-age provisions are either excluded from taxable income and thus pension benefits are subject to taxation, or contributions are paid out of taxed income implying that pensions are non-taxable income during retirement. Our model explicitly deals with the timing of tax and pension payments by using an inter-temporal approach.

\subsection{Results}

The base case represents the IBC Taxation Index for highly skilled manpower. Here, we consider an employee demanding a disposable income of $€ 100,000$. The total remuneration paid by the employer in order to meet the employee's demand consists of $75 \%$ cash compensation, $20 \%$ old-age contributions, and 5\% benefits in kind. The employee is single and has no other income. The resulting effective tax burdens form four groups (see Table 3): The first group is with the Swiss cantons Schwyz, Zug, and Nidwalden reveal the lowest tax burdens of less than $30 \%$. The second group with moderate tax burdens between $30 \%$ and $40 \%$ consists of the other cantons analysed, the United States, Poland, Luxembourg, and the United Kingdom. High tax burdens with effective tax rates between $40 \%$ and $50 \%$ occur in Ireland, Slovakia, Austria, the Netherlands, Czech Republic, Hungary, Germany, France, and Italy. Slovenia, Sweden, Belgium, and Finland display the highest effective tax rates with more than $50 \%$.

To illustrate these differences, it is instructive to translate back the EATRs into the total remuneration required in each location so as to provide the employee with a disposable income of $€ 100,000$. To achieve this, a company has to spend $€ 134,574$ in Schwyz, $€ 161,740$ in Massachusetts, and $€ 230,415$ in Finland. Thus, taxes interfere heavily in the international competition for talent.

The most important tax drivers influencing the effective tax rates on highly skilled labour are the top tax rate of the personal income tax and the amount of charges paid within the contributions to social security.

Regarding the top tax rates (including state/cantonal income taxes and surcharges), the Swiss cantons Zug, Schwyz, and Nidwalden again form a group with the lowest top tax rate. They display top tax rates (including cantonal and municipal income taxes) of less than $30 \%$. The second group with top tax rates between $30 \%$ and $40 \%$ is formed by the Czech Republic, the Swiss Canton of St. Gall, Luxembourg, and Slovakia. Top tax rate of at least 50\% apply in Austria, Slovenia, Germany, Finland, the Netherlands, Belgium, and Sweden. The remaining countries levy taxes of between $40 \%$ and $50 \%$ at the top. 
This ranking is widely reflected in the effective tax rates. However, the corresponding incomes from which on the top tax rates apply also are an important factor. In the Czech Republic and in Hungary, tax payers with incomes of $€ 10,000$ and of $€ 5,000$, respectively, already achieve the top tax rates of $32 \%$ and $40 \%$. Despite comparably low tax rates, those two countries find themselves in the last third in the ranking. Austria and the Netherlands with top tax rates of $50 \%$ and more display lower EATRs due to a higher progressivity in their tax tables and capped social security contributions. Especially for the United States and Switzerland, where the top tax rates often apply only for incomes exceeding $€ 200,000$ and more, the EATRs for a disposable income of $€ 100,000$ are far below the top tax rates.

Regarding the charges payable on a highly qualified employee's income, the most important impact is the existence or absence of income ceilings from which on no further social security contributions are payable. Only in Austria, Germany, Luxembourg, the Netherlands, Slovakia, and the United States income ceilings exist for all branches of social security for both the employee and the employer. In particular, a low ceiling of $€ 9,300$ applies in Slovakia; the Netherlands have ceilings of around $€ 30,000$. However, the contribution rates are comparably high with more than $40 \%$ of gross income. Belgium, Switzerland, the Czech Republic, Finland, and Slovenia do not apply any income ceiling for social insurance contributions. So, the total contribution rate is payable on all income. While Switzerland therefore has a comparably low total contribution rate of less than 15\% Slovenia and Belgium levy contributions at rates of around $40 \%$. This results in high EATRs for Slovenia and Belgium. Combined with high top tax rates, the EATRs amount to over 50\%. Belgium is on the second-to-last rank; Slovenia ranks fourth-to-last.

The model allows evaluating the effects of a large number of different economic and personal circumstances. For example, all regions grant tax relief for families in the form of child benefits or special tax schedules depending on marital status and the number of children. The results of the model show that families in Germany, Ireland, the USA, France, and Switzerland enjoy a particularly strong reduction of their tax burden relative to singles (see Elschner and Schwager, 2004 and 2005).

While any variation obviously affects the calculated EATRs, sensitivity analyses show that the ranking of EATRs is quite robust to changes in specific assumptions of the model. In all cases Zug, Schwyz, and Nidwalden have the lowest tax rates, usually followed by the remaining Swiss cantons, the United States, Poland, Luxembourg, and the United Kingdom. Slovenia, Sweden, Belgium, and Finland change ranks among each other but most of the time remain at the high end of the scale. The new EU Member States are not inevitably attractive countries from the tax perspective if one looks at the taxation of highly qualified employees. In contrast to the tax burden on companies they rather show a moderate or even high tax burden on skilled manpower.

\section{Tax Policy Strategies: Explanations and Implications}

In this section, we provide a synthesis of the findings about the effective tax burdens of both companies and highly skilled manpower. In the first subsection, we aim at identifying tax policy strategies pursued by the countries analysed. In the second subsection, we discuss several hypotheses which might explain the diversity found among these strategies. While this discussion necessarily remains speculative without a thorough empirical analysis, it will nevertheless present some insights into the political motives and economic circumstances which may have caused the levels of taxation found in our study. This is important since any policy advice to be derived from our figures should take into account the likely political aims and the 
special situation of each country. The discussion of political implications is the purpose of the final subsection.

\subsection{A synthesis of both indicators}

Fig. 2 provides a synthesis of the two indicators for the effective tax burden of companies and on highly qualified employees. For five Swiss cantons and the other countries, this figure displays the EATR at the corporate level together with the EATR of a single-earner employee obtaining a disposable income of $€ 100,000$ in 2003. Due to a number of conceptual differences, we cannot compare the absolute values of the IBC Taxation Indexes for companies and for highly qualified employees. Especially, both concepts of effective tax burdens do not permit straightforward conclusions on distributional issues. Nevertheless, we can compare the rankings and the relative differences in effective tax burdens between both indicators.

For this purpose, we index the effective tax burdens of all countries and the Swiss cantons relative to the average of the included Swiss cantons and the other countries. A canton or country with an index number 100 for the taxation of companies (highly skilled employees) thus has an EATR for companies (highly skilled employees) which equals the average of all cantons and countries considered. The vertical (horizontal) distance between an observation and the axes shows how much lower or higher a location's effective tax burden is compared to the average in the case of companies (manpower).

It is striking that effective tax burdens appear to be closely correlated for a number of locations. Especially for Swiss cantons, we find a low level of effective tax burdens of companies and a low tax burden on highly skilled workers. Other regions that impose large corporate tax burdens also impose large tax burdens on comparatively high personal incomes, especially Germany, France, and Italy. Thus, the Swiss cantons follow a clear low tax strategy with respect to both companies and highly skilled manpower while the other three countries mentioned can be characterized as high-tax countries in both respects. Also Austria, the Netherlands, the United Kingdom, Luxemburg, and Poland display a point on or somewhat above a hypothetical diagonal in Figure 2, indicating a similar ranking in both indicators. The level of taxation is at an intermediate level in both respects for these countries.

There is a group of countries which tax highly qualified employees quite heavily while taxing companies only moderately. Especially Hungary and Slovenia have low tax burdens for companies but highly skilled employees suffer a comparatively high tax burden there. This holds also for Sweden and Finland, which both have dual income tax systems with low tax rates on capital and high tax rates on employment income. Although less clear cut, also Belgium and, with a lower overall level of tax burden, Slovakia and the Czech Republic, can be associated to this group. The most pronounced example for this group obviously is Ireland, which almost matches the most favourable Swiss location in terms of company tax burden while imposing an effective tax rate on skilled manpower which is close to the mean of the regions considered. The tax policy strategy chosen by these countries apparently consists of selectively reducing the tax burden on companies while keeping labour income taxation at relatively high levels.

Finally, the United States (Massachusetts) differs remarkably from all other countries analysed. There, the tax burden on companies is among the highest of all regions considered, while qualified employees are taxed quite moderately. Thus, the strategy of the United States 
consists of very moderate taxation of high earners combined with a substantial tax on company income.

\subsection{Why do countries choose different tax policy strategies?}

We group the potential determinants of the tax policies chosen by different countries into three categories. The first two of these, political institutions and preferences for redistribution and equality, essentially determine the amount of government revenues required. The third category, position in the processes of globalisation and growth, mainly explains strategies in company taxation.

\section{Institutions.}

Given the remarkably low effective tax rates in Switzerland, it is natural to think of direct democracy as an important institutional determinant of the tax burden. There is indeed an ample body of research analysing tax policy in Swiss cantons and municipalities which confirms this hypothesis. For example, Feld and Matsusaka (2003) and Feld and Kirchgässner (2001) show that localities with referenda on tax policy have lower levels of government spending and taxation compared to those in which parliament decides alone.

In representative democracies, the electoral system may have an impact on the overall tax burden. In countries with proportional representation, coalition governments are common, while in countries with a plurality system, typically one winning party alone forms a government. Since in a coalition more special interests are represented, it is harder for such a government to reduce spending since they have to please all those interests. Thus taxes are likely to remain high (see Persson and Tabellini, 1999, 2001, Milesi-Ferretti et al, 2002, and Stegarescu, 2005). A similar effect may be at work in countries with a bicameral or presidential system where law making effectively needs the consensus of both major political camps. The high effective tax rates in Germany, Italy, and France fit this explanation. Conversely, the fact that the United Kingdom taxes more moderately may be attributed to the generally clear majority of the ruling party in Britain's Lower House.

A further characteristic distinguishing Switzerland from most of the other countries is her federal structure and the strong tax autonomy enjoyed by jurisdictions at the subnational level. Since Swiss cantons and municipalities experience tax competition even inside their own country, they have a stronger incentive to keep tax burdens on mobile capital low than a unitary state where such internal tax competition is absent. As shown by recent theoretical (Keen and Kotsogiannis, 2002) and empirical (Esteller-Moré and Solé-Ollé, 2001) research, however, the joint exploitation of the same tax base by several layers of the state induces excessively high tax rates in federations. A similar effect occurs when local jurisdictions participate in a system of equalizing grants (see Bucovetsky and Smart, 2002, Büttner and Schwager, 2003). Despite the unquestionable relevance of tax competition on the municipal level, Germany has exceptionally high effective tax burdens on companies.

Preferences for redistribution.

Alesina et al. (2001) discuss the causes for the different extent of the welfare state in the United States and Europe. Based on many indicators, they show that the majority of the population in the United States are much less inclined to support the poor and to redistribute income via the public budget than the electorate in most European countries. By consequence, the higher overall level of taxation in most continental European countries may simply reflect the citizens' stronger taste for redistribution. In that respect, the two English speaking Euro- 
pean nations in our sample, the United Kingdom and Ireland, seem to be closer to the United States than to Europe.

Similar to a revenue requirement deriving from flaws in the electoral system, also the revenue requirement originating from a desire to redistribute income mainly explains the tax burden on employees. Nevertheless, the tax burden on capital may in itself be considered an issue for social justice, in the sense that equity requires to tax capital at least as heavily as labour income. If this is the case, a high effective tax rate for companies follows from a strong demand for redistribution alongside a high tax burden on qualified labour.

\section{Globalisation and growth.}

The position of a country in the growth process may be important for her choice of tax strategy since it affects the benefits and costs of taxing capital for redistributive reasons. Whereas the countries in our sample belonging to the EU 15, with the exception of Ireland, are characterized by a high GDP per capita and low growth rates, the accession countries are fast growing, but starting from a very low level. By consequence, in the EU accession countries there is very little capital which could be expropriated by taxation, implying that it is not really worthwhile to impose high corporate income taxes. Contrary to that, company taxation in the EU 15 countries generally promises substantial revenue and thus a high effective tax rate on companies is attractive.

The cost of redistributing income by capital taxation is also closely linked to a country's growth rate. It is likely that in relatively poor countries, a high effective marginal tax rate on investment is particularly harmful in terms of foregone growth since the potential for growth is still large in such countries. It is striking that in our sample, the Eastern European countries typically choose a strategy of low or very low company taxation, combined with a relatively high tax on skilled employees. In 2004 this strategy of the enlargement countries is confirmed by a further significant decrease of the company tax burden in Poland and the Slovakia. Thus, while these societies seem to adhere to the continental European model of the welfare state, they are not ready to jeopardize their growth prospects by taxing corporate investment heavily. An observation confirming this conclusion is the prevalence of specific investment incentives e.g. in Slovenia and the Czech Republic which particularly reduce EMTRs, the measure of tax burden relevant for the level of investment.

All countries are exposed to globalisation, but not all are so to the same degree. According to international trade theory, small countries generally benefit from international trade and factor movements and thus are more open than large countries. Consequently, small countries should be more aware of tax induced international relocation of capital than large countries. Since EATRs are relevant for location decisions, this fact implies that we should expect small open countries to display comparatively low EATRs, whereas large countries are more likely to stick to high EATRs despite globalisation. The results are largely in line with this hypothesis. The big European countries Germany, France, and Italy impose high effective tax burdens on companies while smaller countries like Switzerland, Ireland, Hungary, Slovenia, Sweden, Finland, Luxemburg, and Belgium display lower company tax burdens. This is particularly remarkable in the cases of Belgium and the two Scandinavian countries which definitely do not follow a general low tax - low spending strategy. Instead, these countries keep personal income taxes high so as to finance the desired amount of expenditure, but they explicitly want to attract internationally mobile firms by reducing company tax burdens, for example by a dual income tax regime. The most striking example here is probably the United States. Despite a culture of low state involvement and low taxes, the US tops the list of effective average tax rates on companies. A possible explanation for this fact is that the US is so large that 
an international relocation of production is relevant for only a small fraction of her companies. By consequence, the pressure to keep profit taxes low is felt much less intensely than in other countries.

There is yet another possible interpretation of the strategy pursued by the USA, France, Germany, and Italy in the process of globalisation. Since companies do not only pay taxes but also benefit from public infrastructure, it might be that these countries try to position themselves as suppliers of high value public goods which are worth the high price in terms of taxes. Compared with the Eastern European countries, the superior infrastructure in these countries certainly compensates to some extent for the tax differential. However, Switzerland, the Scandinavians, and Luxemburg are able to offer a similar package of public services together with lower tax rates, not to mention Ireland. Thus, the benefit provided by high taxes can at best explain a small part of the difference in EATRs measured.

\subsection{Policy Implications}

For Germany, the results of our study bear the clear message that, despite recent reforms, effective tax rates are still high in comparison with other countries. Inasmuch as high taxes are considered to be harmful for growth, Germany should reinforce her efforts in reducing the overall tax burden, especially for companies. However, the above discussion suggests that a majority of the German population may be willing to accept lower growth as a price to be paid for social justice. In particular, the Nordic and Eastern European strategy of selectively reducing corporate income taxes is inconsistent with the ideas of distributional justice held by some commentators in Germany (Kirchhof, 2002).

It is possible, however, that a consensus is about to emerge in Germany to accept lower public spending so as to be able to reduce tax burdens. If this is the case, institutional reforms may be helpful to promote a tax-reducing agenda. The collusive behaviour of state and federal governments in deciding tax policy may be a major cause for persistently high taxes (cf. Blankart, 2000). By consequence, a more decentralised allocation of powers to legislate taxes, with some tax autonomy on the part of the Länder, might help to reduce effective tax rates in Germany. The Swiss example furthermore suggests that referenda on fiscal issues could be a way of curbing government spending and reducing tax rates.

For the European Union, the policy conclusions are different. On average, Europe does not suffer from poor growth, implying that an overall reduction in tax rates is probably not the top priority. On the other hand, the strong dispersion in EATRs across EU countries may cause firms to choose locations according to tax differentials rather than according to productivity (see Devereux et al., 2003). The ensuing inefficiency will be reduced by a co-ordinated tax base.

Several caveats are appropriate here, however. First, as shown by Sørensen (2004), a harmonisation of capital income taxes restricted to the European Union is likely to provide only moderate welfare gains. Second, harmonisation of taxes may be harmful if it allows selfinterested politicians to extract political rents from the citizens (see Edwards and Keen 1996). Given that in the EU, decision procedures are certainly not closer to the individual citizens than in the member states, a transfer of taxing power to the European Union should be handled with care. 
Finally, low corporate income taxes appear to be an integral part of the growth strategy of the new member states. It would be short-sighted to take this instrument away from these countries. If forced to raise their tax rates, they probably will react by intensifying competition in other location factors such as labour market or environmental regulation. Most importantly, because of intensified trade and reduced regional aid, the EU 15 countries will probably benefit more from dynamic growth in the recent member states than they lose through tax induced relocation of companies.

\section{Summary and Conclusions}

Under competitive markets for capital and highly skilled manpower, company taxes and taxes on highly skilled labour both influence the attractiveness of a particular region as a location for investment. By measuring the effective tax burden on capital investment and on highly qualified labour for 33 selected locations across Europe and the United States, we find that there is great dispersion in the effective tax rates of both factors of production. Based on that analysis, the aim of this paper is to combine these findings and to study the correlation of both types of tax burden. By doing so, we obtain a more complete picture of tax policy strategies pursued by the countries studied.

We identify three potential causes in order to explain the different tax policy strategies of different countries: (1) political institutions, (2) preferences for redistribution and equality, and (3) the position in globalisation and growth. Our findings on the effective tax rate of companies and highly skilled manpower strongly reflect these different tax strategies. However, each country shows a mix of tax strategies which lead to the country-specific tax burdens. Small countries, high growth rates, and federal structure with high tax autonomy stand for countries that offer lower tax burdens, especially on companies. As examples for this group of countries we can identify e. g. Ireland and Switzerland, however, each with certain limitations. Most new EU member states follow a strategy of taxing companies comparatively low, but offer only an average tax climate for highly skilled employees. Large countries, representative democracies with coalition governments, and a high preference for redistribution are likely to induce higher tax burdens on both highly qualified employees and companies and thus are less attractive locations for an investment from a tax perspective. As typical examples for this group of countries, we identify Germany, France, and Italy. The low tax rates for the highly skilled in the United States therefore stand for her plurality system, her federal structure, and a population with low preference for redistribution. Due to her size the United States do not need to tax companies at low rates.

Future research aims at further examining, and substantiating, these conclusions. As an example for such an extension, an analysis of the taxation of highly qualified expatriate staff might be of interest. Indeed, the growing number of countries offering special tax regimes for such employees supports the hypothesis that many countries pursue a strategy to tax mobile factors low and immobile factors high. With an increasing number of international assignments, the potential impact of these special tax regimes on the investment decisions of companies offers a promising field for future research. 


\section{Appendix}

Table 2: Company Taxation: Effective Average Tax Rates (EATR) and Effective Marginal Tax Rate (EMTR) at the Corporate Level, 2003

EATR (\%) $\quad$ EMTR (\%)

IBC Taxation Index on Companies

\begin{tabular}{lcc}
\hline CH-Zug & 13.8 & \\
Ireland & 14.0 & 7.1 \\
CH-Nidwalden & 15.4 & 11.9 \\
CH-Schwyz & 16.5 & 9.0 \\
CH-Ticino & 18.5 & 10.6 \\
CH-Bern & 18.6 & 12.2 \\
Hungary & 19.4 & 10.6 \\
CH-Valais & 19.7 & 18.9 \\
CH-St. Gallen & 20.3 & 14.7 \\
CH-Vaud & 20.5 & 6.9 \\
Slovenia & 20.8 & 13.1 \\
CH-Zurich & 21.0 & 10.0 \\
Slovakia & 21.3 & 13.6 \\
CH-Geneva & 21.4 & 12.0 \\
CH-Basel & 22.1 & 14.5 \\
Sweden & 22.5 & 15.6 \\
CH-Basel Landschaft & 22.8 & 15.1 \\
Czech Republic & 23.5 & 16.3 \\
Poland & 23.7 & 17.4 \\
Luxembourg & 25.8 & 16.1 \\
Finland & 26.5 & 14.7 \\
United Kingdom & 28.1 & 21.2 \\
Belgium & 28.7 & 24.2 \\
Netherlands & 30.2 & 16.3 \\
Austria & 30.4 & 21.1 \\
Italy & 31.8 & 22.9 \\
France Min. (Paris) & 32.1 & 18.9 \\
Germany Min.(Weilheim) & 32.9 & 25.5 \\
France Med. (Doubs) & 34.5 & 23.6 \\
Germany Med. (Heilbronn) & 34.8 & 32.9 \\
France Max. (Isère) & 35.7 & 25.7 \\
United States & 36.0 & 36.2 \\
Germany Max. (Frankfurt) & 37.3 & 25.8 \\
\hline & & 28.4 \\
\hline & $c 0.3$ & $7 \mathrm{~V}$ \\
\hline
\end{tabular}

Remarks: $\mathrm{CH}=$ Switzerland. For Austrian corporations that can take maximum advantage of the dual income tax system and the incremental investment tax credit, the EATR reduces to 26.1 per cent and the EMTR reduces to 3.3 per cent. For Luxembourgian companies, which can use the tax credit for supplementary investment, the EATR is $23.6 \%$ and the EATR is reduced to $4.5 \%$, and for Slovenian companies, which can take full advantage of the investment tax credit and the tax exempt reserve, the EATR is reduced to $15 \%$ and the EMTR is $-11 \%$. 
Table 3: Effective average tax rates on highly qualified manpower, 2003

\begin{tabular}{lclc}
\hline \multicolumn{2}{c}{$\begin{array}{c}\text { Single employee } \\
\text { IBC Taxation Index on Highly Skilled Manpower } \\
\text { EATR in \% }\end{array}$} & & Married employee with two children \\
\hline CH Schwyz & 25.7 & CH Zug & EATR in \% \\
CH Zug & 25.9 & CH Schwyz & 20.9 \\
CH Nidwalden & 28.3 & CH Nidwalden & 22.0 \\
CH Zurich & 32.6 & Luxembourg & 25.0 \\
CH Valais & 35.4 & CH Zurich & 26.0 \\
CH Basel Landschaft & 36.6 & CH St. Gallen & 26.7 \\
CH St. Gallen & 36.8 & United States & 30.2 \\
CH Bern & 36.8 & CH Basel Landschaft & 31.3 \\
CH Basel & 36.9 & CH Vaud & 31.3 \\
CH Geneva & 37.9 & CH Valais & 31.4 \\
CH Ticino & 38.2 & CH Bern & 31.5 \\
United States & 38.2 & CH Ticino & 31.9 \\
Poland & 38.6 & CH Basel & 32.0 \\
Luxembourg & 39.2 & CH Geneva & 32.1 \\
United Kingdom & 39.2 & Germany & 33.9 \\
CH Vaud & 39.3 & Ireland & 35.2 \\
Ireland & 40.3 & Poland & 35.8 \\
Slovakia & 40.7 & United Kingdom & 36.8 \\
Austria & 41.7 & Austria & 37.4 \\
Netherlands & 42.9 & France & 38.2 \\
Czech Republic & 43.6 & Netherlands & 39.4 \\
Hungary & 45.2 & Slovak Republic & 40.2 \\
France & 47.3 & Czech Republic & 40.4 \\
Germany & 47.6 & Hungary & 43.2 \\
Italy & 49.8 & Italy & 44.9 \\
Slovenia & 51.2 & Belgium & 49.2 \\
Sweden & 51.8 & Slovenia & 50.3 \\
Belgium & 54.0 & Sweden & 50.5 \\
Finland & 56.6 & Finland & 51.1 \\
\hline \hline & Remark The & 55.4 \\
\hline
\end{tabular}

Remarks: The disposable income of $€ 100,000$ is calculated with a compensation package of 75 per cent cash, 5 per cent benefits in kind, and 20 per cent old-age contributions.

Source: ZEW/BAK. 
Fig. 2: Correlation of Company Tax Burdens and Tax Burdens on Highly Skilled (2003).

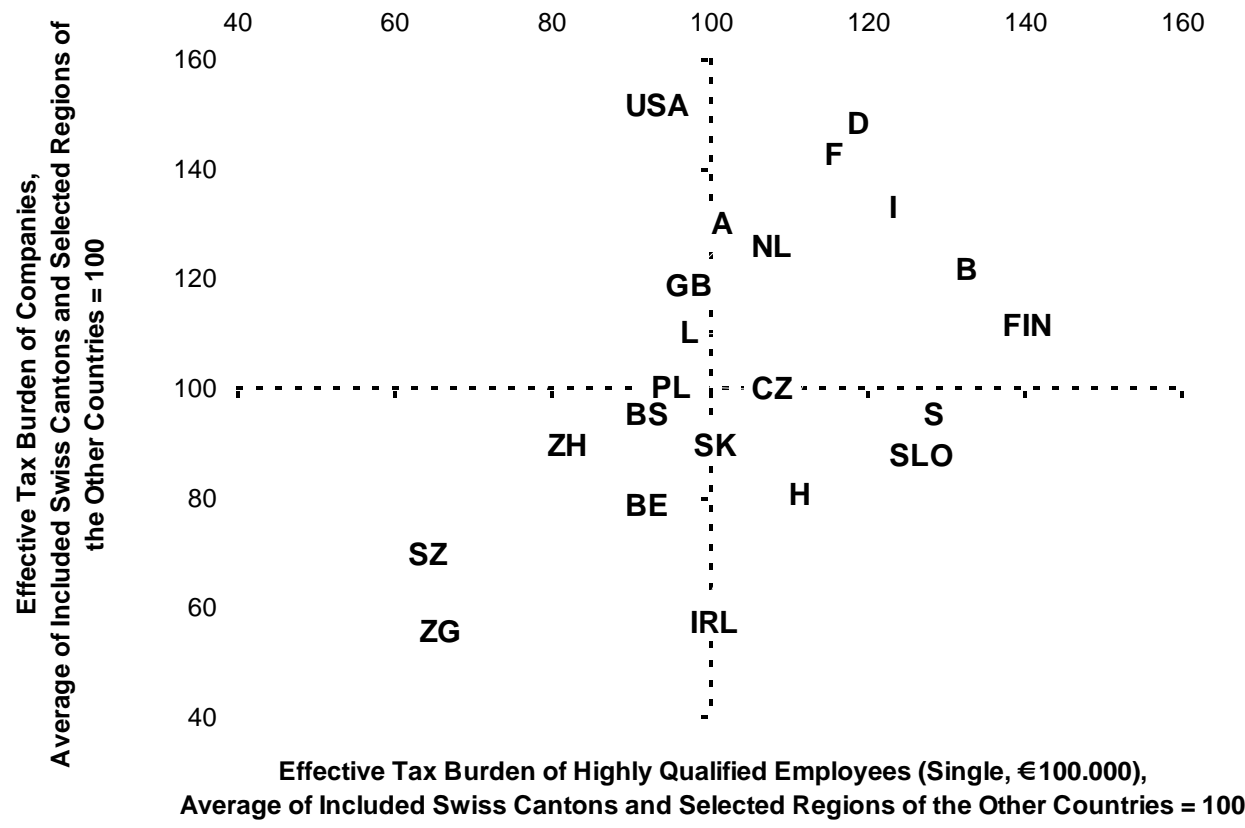

\begin{tabular}{|c|c|c|c|c|c|c|c|c|c|c|c|c|}
\hline $\begin{array}{l}\text { Effective tax } \\
\text { burden on ... }\end{array}$ & $\mathrm{BE}$ & BS & $\overline{S Z}$ & ZG & $\mathrm{ZH}$ & & & A & B & $\mathrm{CZ}$ & $\mathrm{D}$ & $\bar{F}$ \\
\hline $\begin{array}{l}\text { highly skilled } \\
\text { manpower }\end{array}$ & 90.7 & 90.9 & 63.2 & 63.7 & 80.1 & & & 102.6 & 132.9 & 107.3 & 117.2 & 116.3 \\
\hline companies & 78.8 & 93.8 & 70.1 & 58.6 & 89.4 & & & 129.2 & 121.9 & 99.8 & 148 & 146.5 \\
\hline $\begin{array}{l}\text { Effective tax } \\
\text { burden on ... } \\
\end{array}$ & FIN & GB & $\mathrm{H}$ & I & IRL & L & NL & PL & $S$ & SK & SLO & USA \\
\hline $\begin{array}{l}\text { highly skilled } \\
\text { manpower }\end{array}$ & 139.3 & 96.5 & 111.3 & 122.5 & 99.2 & 96.5 & 105.6 & 95 & 127.5 & 100.2 & 126 & 94 \\
\hline companies & 112.6 & 119.4 & 82.4 & 135.1 & 59.5 & 109.6 & 128.5 & 100.7 & 95.6 & 90.5 & 88.4 & 152.9 \\
\hline
\end{tabular}

Remarks: BE = Bern, BS = Basel, SZ = Schwyz, ZG = Zug, ZH = Zurich, CH= average of 7 additional Swiss Cantons; $\mathrm{A}=$ Austria; $\mathrm{B}=$ Belgium; $\mathrm{CZ}=$ Czech Republic; $\mathrm{D}=$ Germany; $\mathrm{F}=$ France; FIN = Finland; GB = United Kingdom; $\mathrm{H}$ = Hungary; I = Italy; IR = Ireland; NL = the Netherlands; PL = Poland; S = Sweden; SK = Slovakia; SLO = Slovenia; US = United States. With the exception of Switzerland, we have chosen the median value for those countries that demonstrate regional variation in company tax burdens. Source: ZEW/BAK. 


\section{References}

Alesina, A., E. Glaeser, and B. Sacerdote (2001), Why Doesn't the US Have a Europeanstyle Welfare System? NBER Working Paper Series 8524.

Blankart, C. (2000), The Process of Government Centralization: A Constitutional View, Constitutional Political Economy 11, 27-39.

Bucovetsky, S. and M. Smart (2002), The Efficiency Consequences of Local Revenue Equalization: Tax Competition and Tax Distortions, CESifo Working Paper 767, Munich.

Büttner, T. and R. Schwager (2003), Länderautonomie in der Einkommensteuer: Konsequenzen eines Zuschlagsmodells, Jahrbücher für Nationalökonomie und Statistik 223, 532-555.

Büttner, T. and M. Ruf (2004), Tax Incentives and the Location of FDI: Evidence from a Panel of German Multinationals, ZEW Discussion Paper 04-76, Mannheim.

De Mooij, R. and S. Ederveen (2003), Taxation and Foreign Direct Investment: A Synthesis of Empirical Research, International Tax and Public Finance 10, 673-693.

Devereux, M.P. and R. Griffith (1998), Taxes and the Location of Production: Evidence from a Panel of US Multinationals, Journal of Public Economics 68, 335-367.

Devereux, M.P. and R. Griffith (1999), The Taxation of Discrete Investment Choices, IFS Working Paper 98/16 (Revision 2), London.

Devereux, M.P. and R. Griffith (2003), Evaluating Tax Policy for Location Decisions, International Tax and Public Finance 10, 107-126.

Devereux, M.P., L. Lammersen, and C. Spengel (2000), The Effective Levels of Company Taxation in the Member States of the EU, Report Prepared for the Taxation and Customs Union Directorate General, Warwick.

Devereux, M.P., L. Lammersen, and C. Spengel (2001), Changes in the Effective Levels of Company Taxation in the Member States of the EU: 1999 to 2001, Supplementary Report Prepared for the Taxation and Customs Union Directorate General, Mannheim and Warwick.

Devereux, M.P., L. Lammersen and C. Spengel (2003), Corporate Taxes and Economic Efficiency in Europe, in: R. Madhusudhan (ed.), Proceedings of the $95^{\text {th }}$ Annual Conference on Taxation, Washington, 226-235.

Edwards, J. and M. Keen (1996), Tax Competition and Leviathan, European Economic Review 40, 113-134.

Elschner, C. and R. Schwager (2004), A Simulation Method to Measure the Tax Burden on Highly Skilled Manpower, ZEW Discussion Paper 04-59, Mannheim.

Elschner, C. and R. Schwager (2005), The Effective Tax Burden on Highly Qualified Employees: An International Comparison, ZEW Economic Studies 29, Heidelberg. 
Esteller-Moré, A. and A. Solé-Ollé (2001), Vertical Income Tax Externalities and Fiscal Interdependence: Evidence from the US, Regional Science and Urban Economics 31, 247-272.

European Commission (2002), Company Taxation in the Internal Market, Commission Staff Working Paper COM (2001) 582 final, Luxembourg.

Feld, L. and G. Kirchgässner (2001), The Political Economy of Direct Legislation: Direct Democracy and Local Decision-Making, Economic Policy 16s, 329-367.

Feld, L. and J. Matsusaka (2003), Budget Referendums and Government Spending: Evidence from Swiss Cantons, Journal of Public Economics 87, 2703-2724.

Gutekunst, G. and R. Schwager (2002), Steuerbelastung von Unternehmen im Alpenraum, ZEW Wirtschaftsanalysen 59, Baden-Baden.

Jacobs, O.H., C. Spengel, M. Finkenzeller, and M. Roche (2004), Company Taxation in the New EU Member States, Second Edition, Frankfurt.

Keen, M. and C. Kotsogiannis (2002), Does Federalism Lead to Excessively High Taxes?, American Economic Review 92, 363-370.

King, M.A. and D. Fullerton (1984), The Taxation of Income from Capital, Chicago.

Kirchhof, P. (2002), Maßstäbe für die Ertragsbesteuerung von Unternehmen - Eröffnung der Jahrestagung und Rechtfertigung des Themas, in F.S. Seeger, Perspektiven der Unternehmensbesteuerung, Deutsche Steuerjuristische Gesellschaft 25, Köln, 1-8.

Lammersen, L. and R. Schwager (2004), Die steuerliche Attraktivität der Schweiz als Unternehmensstandort im internationalen und interregionalen Vergleich, Internationales Steuerrecht $13,741-749$.

Lammersen, L. and R. Schwager (2005), The Effective Tax Burden of Companies in European Regions: An International Comparison, ZEW Economic Studies 28, Heidelberg.

Milesi-Ferretti, G.M., R. Perotti, and M. Rostagno (2002), Electorial Systems and Public Spending, Quarterly Journal of Economics 117, 609-657.

OECD (2002), Taxing Wages 2001-2002, Paris.

Persson, T. and G. Tabellini (1999), The Size and Scope of Government: Comparative Politics with Rational Politicians, European Economic Review 43, 699-735.

Persson, T. and G. Tabellini (2001), Political Institutions and Policy Outcomes: What are the Stylized Facts?, CEPR Discussion Paper 2872

Richter, W., H. Seitz and W. Wiegard (1996), Steuern und unternehmensbezogene Staatsausgaben als Standortfaktoren, in: H. Siebert (ed.), Steuerpolitik und Standortqualität: Expertisen zum Standort Deutschland, Tübingen, 13-47.

Sachverständigenrat zur Begutachtung der gesamtwirtschaftlichen Entwicklung, (2001), Für Stetigkeit - gegen Aktionismus (Jahresgutachten 2001/02), Wiesbaden. 
Sachverständigenrat zur Begutachtung der gesamtwirtschaftlichen Entwicklung (2003), Staatsfinanzen konsolidieren - Steuersystem reformieren (Jahresgutachten 2003/04), Wiesbaden.

Schreiber, U., C. Spengel, and L. Lammersen (2002), Measuring the Impact of Taxation on Investment and Financing Decisions, Schmalenbach Business Review 54, 2-23.

Sørensen, P.B. (2004), International Tax Coordination: Regionalism versus Globalism, Journal of Public Economics 88, 1187-1214.

Spengel, C. (2003), Internationale Unternehmensbesteuerung in der Europäischen Union, Düsseldorf.

Stegarescu, D. (2005), Costs, Preferences, and Institutions: An Empirical Analysis of the Determinants of Government Decentralisation, mimeo.

Sutherland, H. (2001), Final Report Euromod: An Integrated European Benefit-Tax Model, Euromod Working Paper No. EM9/01.

Winkelmann, R. (2002), Why Do Firms Recruit Internationally? - Results from the IZA International Employer Survey 2000, in: OECD, International Mobility of the Highly Skilled, Paris.

Winkelmann, R., A. Kunze, L. Locher, and M. Ward (2001), Die Nachfrage nach internationalen hochqualifizierten Beschäftigten - Ergebnisse des IZA International Employer Surveys 2000, IZA Research Report 4, Bonn. 